\title{
K PROBLEMATICE PŘEVODU TOPONYM MEZI ČEŠTINOU A POLŠTINOU - EXONYMA A ENDONYMA
}

\section{MARIE GRIGOVÁ}

\section{ON THE ISSUE OF TOPONYMS CONVERSION BETWEEN CZECH AND POLISH - EXONYMS AND ENDONYMS}

ABSTRACT The article deals with the transfer of geographical names between Czech and Polish. It defines the terms endonymy and exonymy terminologically. It examines the scope of codification and official lists of geographical names and exonyms. It also discusses the issue of awareness of users of a given language of the existence of these lists and the frequency of their use.

KEY WORDS endonyms, exonyms, toponyms, translation, Czech, Polish

CONTACT Sekce polské filologie katedry slavistiky FF UP Olomouc;

marie.grigova@upol.cz 
V českých textech pojednávajících o polských reáliích a vice versa naráží jejich autoři či překladatelé často na zásadní problém v podobě převodu zeměpisných názvů. V každém ze zmíněných jazyků existují oficiální seznamy tzv. exonym, které mají pomoci při volbě vhodného ekvivalentu. Závaznost a rozsah těchto seznamů jsou však v obou jazycích odlišné. Cílem tohoto článku je zmapovat situaci a uvést další př́ípadné zdroje, kde můžeme hledat pomoc při řešení problémů tohoto typu.

Mezi základní publikace zaměřené na tuto problematiku patří práce Edvarda Lotka. Ve své knize Čeština a polština v překladatelské a tlumočnické praxi (Lotko 1989) se zaměřuje na antroponyma i toponyma. Poskytuje rady jak a kdy vlastní jména překládat, jak je správně skloňovat či přechylovat. Jeho další práce, ve které synchronně konfrontoval jazykový systém češtiny i polštiny (Lotko 1997), je východiskem pro další jazykový výzkum i odrazovým můstkem pro překladatelskou praxi mezi češtinou a polštinou.

Jak konstatuje Wojciech Chlebda, byla problematika převodu vlastních jmen až dosud trestuhodně zanedbávána a marginalizována „jak po stránce teoretické, tak i po stránce praktické (slovníkové, poradenské).“(Chlebda - Dobrotová et al. 2015: 23). Slovník pohraničí, zaměřený na areál česko-polského pohraničí, který spolu s Ivanou Dobrotovou redigoval, je jakousi pomyslnou vlaštovkou, která přilétá na pomoc překladatelům, pro něž jsou často vlastní jména velmi tvrdým ořiškem. Při hledání správného ekvivalentu se nejčastěji uchylují k vyhledávání pomocí Wikipedie, jejíž věrohodnost a autorita v této oblasti jistě není stoprocentní, i když zde samozřejmě najdeme články, které jsou řádně ozdrojované.

Při hledání ekvivalentů bychom měli v první řadě čerpat $\mathrm{z}$ oficiálních seznamů exonym či geografických názvů, které přináší záruku, že bude výsledek v souladu se standardizovanou formou. Dále máme k dispozici normativní přiručky (např. Pravidla českého pravopisu) nebo slovníky. Jaké seznamy toponym máme tedy pro češtinu a polštinu v současnosti k dispozici? Je badatelské a standardizační úsilí badatelů v obou zemích stejné? Analýza uvedených seznamů bude východiskem pro další zkoumání jazykového materiálu.

\section{$1 /$ EXONYMA VERSUS ENDONYMA}

Termíny exonymum a endonymum jsou v polské i české onomastice poměrně nové. V českém kontextu se ještě v roce 1981 setkáváme s pojmem vžitá vlastní jména. Tyto pojmy nenajdeme ani v rozsáhlé encyklopedii polských vlastních jmen z roku 1998 (Rzetelska-Feleszko 1998). Rovněž v názvu oficiálního polského úředního seznamu zeměpisných jmen z roku 2013 se vůbec s termínem exonymum nesetkáváme.

Podle definice OSN je exonymum „vlastní jméno užívané v určitém jazyce pro geografický objekt ležící mimo území, na němž má tento jazyk oficiální status, a lišící se svou formou od jména užívaného v oficiálním jazyce nebo jazycích tohoto území". ${ }^{1}$ Jeho opakem je endony-

1 Viz Slovník toponymické terminologie pro standardizaci geografických jmen, Názvoslovná komise ČÚZK, Praha 2019 [online]. heslo č. 081 [cit. 2020-09-06]. Dostupné z: https://www.cuzk.cz/O-resortu/Poradci-aporadni-organy/Nazvoslovna-komise-CUZK/Geograficke-nazvoslovne-seznamy/Slovnik-toponymicke-terminologie_2013.aspx Srov. s polskou definicí In Stownik terminów używanych przy standardyzacji nazw geograficznych, Warszawa 1998 [online]. [cit. 2020-09-06]. Dostupné z: http://ksng.gugik.gov.pl/pliki/publikacje/slownik_terminow.pdf. 
mum, které je definováno jako „jméno geografického objektu v jednom z jazyků vyskytujících se v oblasti, kde se objekt nachází.“2

Autorem obou termínů je australsko-britský geograf M. Arousseau a jejich užívání bylo doporučeno na 2. konferenci OSN o standardizaci geografického názvosloví (Londýn 1972). ${ }^{3}$ Snahy o standardizaci a zjednodušení zeměpisných názvů jsou však mnohem starší. V českém kontextu již v roce 1845 zazníval z Královské české společnosti nauk požadavek, že by se měla cizí jména psát tak, jak je tomu obvyklé v zemi jejich původu (Harvalík 2004: 120). Tyto tendence jsou patrné dodnes a v souvislosti s globalizací a růstem mezinárodní komunikace se zdají být opodstatněné. Na druhou stranu se můžeme setkat $\mathrm{s}$ názory, že násilné potlačování vžitých zeměpisných jmen je nesmyslné a ochuzuje jazyk. Je tedy třeba posuzovat danou situaci vždy př́pad od př́padu a zohledňovat také účel textu. Pokud má usnadnit orientaci v terénu, tak bude užitečnější ponechávat toponymům jejich původní endonymní podobu. Je však třeba brát v potaz úzus a neuchylovat se $\mathrm{k}$ tomuto postupu za každých okolností.

V hodnocení toho, co všechno lze pokládat za exonymum nejsou odborníci jednotní. $V$ metodice OSN se za exonyma nepovažují oficiální přepisy endonym z jednoho písma do druhého (pomocí transkripce), někteří však i takové názvy jako exonyma hodnotí (tzv. konverzní exonyma). Podle některých lingvistů jsou za exonyma považována dokonce i pojmenování, jejichž grafická forma je v přejímajícím i původním jazyce identická (Nový encyklopedický slovník češtiny 2012-2020: EXONYMUM) např. Opole v češtině i polštině.

Při pokusech o kategorizaci a analýzu exonym je třeba si uvědomit, že se v daném jazyce může jejich seznam měnit $v$ důsledku politických i společenských změn a historických událostí, které stojí za přesuny oficiálních hranic některých států, či vysídlováním původního obyvatelstva. Ty zejména v poválečném období způsobily v oblasti zeměpisného názvosloví velké změny. Pokud chápeme exonymum ve smyslu definice OSN, pak máme často do činění se situací, kdy se původní endonymum stalo exonymem. Pro ilustraci můžeme použít např. Stettin - tedy původní německé jméno pro dnešní polský Štětín. Podobně je na tom řada polských zeměpisných jmen označujících místa v oblasti dnešního Českého Těšínska, která byla původně endonymy.

Vznik tradičních exonym je podmíněn vzájemnými kontakty uživatelů různých jazyků. $V$ př́padě sousedních jazyků jako je čeština a polština byly tyto kontakty bezprostřední a uživatelé většinou adaptovali koncovku nebo grafickou podobu toponyma přímo na základě fonetického přepisu. Výsledné pojmenování je tak většinou velmi podobné (ne-li totožné) původnímu endonymnímu pojmenování dané země. Většinou bylo pouze zapotřebí převést polské spř̌žky, nosovky, sykavky či grafém $w$ do českého systému znaků a vice versa, přizpůsobit délky apod. (např. České Budĕjovice-Czeskie Budziejowice).

I v blízkých jazycích však docházelo $\mathrm{k}$ tomu, že se jméno geografického objektu dostalo do přijímajícího jazyka zprostř̌edkovaně. Příkladem může být Olomouc, která má v polštině

2 Viz Slovník toponymické terminologie pro standardizaci geografických jmen, Názvoslovná komise ČÚZK, Praha 2019 [online]. heslo č. 076 [cit. 2020-09-06]. Dostupné z: https://www.cuzk.cz/O-resortu/Poradci-aporadni-organy/Nazvoslovna-komise-CUZK/Geograficke-nazvoslovne-seznamy/Slovnik-toponymicke-terminologie_2013.aspx Srov. s polskou definicí In Stownik terminów używanych przy standardyzacji nazw geograficznych, Warszawa 1998 [online]. [cit. 2020-09-06]. Dostupné z: http://ksng.gugik.gov.pl/pliki/publikacje/slownik_terminow.pdf.

3 Srov. Nový encyklopedický slovník češtiny - heslo Exonymum. 
tradiční exonymum Ołomuniec. Polská forma pojmenování odkazuje spíše na německý tvar Olmütz př́padně na latinské Olomucium. K takovému zprostředkovanému přejímání geografických názvů však dochází mezi češtinou a polštinou spíše sporadicky a je typičtějšś pro jazyky, které si nejsou tolik blízké (geneticky či geograficky).

Pokud nahlédneme do seznamu zeměpisných jmen $\mathrm{v}$ Pravidlech českého pravopisu (Hlavsa et al. 2002), najdeme zde pouze 30 exonymních pojmenování polských geografických objektů a $\mathrm{z}$ toho je většina spojena s nějakou historickou událostí, která nalezla echo v české společnosti (např. Grunwald, Lešno, Malbork, Osvětim, Hnězdno). Druhou skupinu tvoří pojmenování nejvýznamnějších měst (např. Varšava, Krakov, Katovice, Toruň, Štětín) a ve třetí skupině se nachází místa, která leží v blízkosti našich hranic (např. Nisa, Kozlí, Vělička). Tento skromný výběr tak docela věrně odráží spojitost existence exonym s potřebami a preferencemi uživatelů přjímajícího jazyka.

Z diachronního hlediska je množina exonym proměnná a obecně sledujeme tendenci nahrazovat exonyma původními endonymy. ${ }^{4}$ Jako př́klad mưže posloužit již zmíněné Opole, které v Pravidlech českého pravopisu z roku 2002 figuruje jako Opole, zatímco v Česko-polském slovníku (Siatkowski - Basaj 2002) z téhož roku nacházíme tvar Opolí. Tento tvar řadí ve své stati mezi ustupující už v roce 1997 také Rudolf Šrámek (Šrámek 1997: 286) nebo M. Harvalík, který jako ustupující zmiňuje také Vratislav (Harvalík 2004: 105). Jaké je však zděšení překladatele, když zjistí, že v indexu exonym z roku 2019 figuruje tvar Opolí, jako doporučená standardizovaná varianta. Př́klad Opole tak poměrně dobře ilustruje komplikovanost celého problému a bezradnost jazykových uživatelů v takových situacích.

Dalším př́lkladem problematického toponyma jsou polské Glivice (Hlivice, Gliwice). V tomto případě máme na výběr dokonce 3 varianty exonyma. Pro použití původní formy se vyslovují Pravidla českého pravopisu (2002), v Indexu exonym z roku 2019 nacházíme tvar Hlivice 5 a pro tvar Glivice nabádá kupř́lkladu Otův slovník naučný.

Pro uživatele polského jazyka se podobně problematicky jeví např. pojmenování pohoří Jeseníky, které se v seznamech zeměpisných jmen objevuje v několika variantách - Jesioniki, Jeseniki, Jeseníky. ${ }^{6}$ Ještě komplikovanější je převod polského toponyma Zaolzie, které se však vztahuje na oblast v České republice. Jedná se o polonocentrický název, kterým jsou v polštině nazývány oblasti jižně za řekou Olší, kde žije početná polská menšina. Paradoxně tedy nacházíme jako oficiální ekvivalent pro oblast na českém území - pojem České Těšínsko - v polském seznamu zeměpisných jmen (KSNG 2013). Lze však stěží předpokládat, že autor píšící o této oblasti česky, sáhne právě po této polské publikaci. Spíše zamírí na Wikipedii, kde se objevují ekvivalenty Záolží, Zaolzí nebo Záolší, slovníkový server Glosbe pak nabízí navíc varianty Českotěšínsko a Těšínsko. Při konzultaci s Ústavem pro jazyk český bylo sděleno, že v češtině žádná oficiální standardizovaná varianta neexistuje, a tudíž se doporučuje použivat původní polský tvar Zaolzie.

\footnotetext{
$4 \quad$ Viz také články M. Harvalíka z roku 1998 v bibliografii níže.

$5 \quad$ Viz také Podrobná mapa Moravy a Slezska, Praha: V. Neubert a synové, 1922

6 Rozsáhlý komentář k tomuto exonymu najdeme ve Slovníku pohraničí (Chlebda - Dobrotová et al. 2015: 28-29).
} 


\section{2 / ČESKÉ INDEXY EXONYM A SEZNAMY ZEMĚPISNÝCH}

\section{NÁZVŮ}

Při převodu polských zeměpisných názvi̊ do češtiny máme $\mathrm{k}$ dispozici několik základních zdrojů, o něž se můžeme opřít. Prvním typem jsou materiály Českého úřadu zeměměřičského a kartografického (dřive Český úřad geodetický a kartografický). Jedná se o geografické názvoslovné seznamy, které jsou zpracovávány v souladu s rezolucí č. 4, část E I. konference OSN o standardizaci geografického názvosloví (Ženeva 1967) a s rezolucí č. 2 III. konference OSN o standardizaci geografického názvosloví (Atény 1977). Ve starších publikacích tohoto typu se $\mathrm{v}$ češtině místo pojmu exonymum použival termín vžité vlastní jméno.

Pokud jde o polské geografické objekty, je počet hesel v těchto seznamech spíše skromný. Ve vydání z roku 1981 (Čáslavka - Štusáková - Vyskočilová 1981), kde je mimo celkového abecedního seznamu rovněž praktický seznam exonym rozčleněný podle zemí, kde se vyskytují, uvedeno pouze 50 českých exonym pro polské zeměpisné objekty. V novějším vydání Indexu exonym z roku 2006 (Beránek et al. 2006) již bohužel rozdělení podle jednotlivých zemí nenajdeme. Pro Polsko je zde však tentokrát dle naší rešerše uvedeno 121 českých exonym. Kromě standardizovaných variant, které tento index doporučuje, jsou zde uvedena v některých př́padech nestandardizovaná exonyma (nejsou uvedena tučně) a výrazy uvedené kurzívou představují zastaralá, málo užívaná nebo regionální nestandardizovaná exonyma. Slabinou těchto seznamů je pro lingvisty absence jakýchkoliv slovotvorných či gramatických komentářu - což však souvisí s prvotním účelem a hlavní cílovou skupinou těchto publikací. Navíc působí výběr objektů mnohdy nekoncepčně a nahodile.

Další příručka tohoto typu vyšla v roce 2011 a uvádí pro Polsko 147 exonym. Nejnovější Index českých exonym (Český úřad zeměměřický a katastrální 2019) mají uživatelé češtiny k dispozici ke stažení na stránkách Geoportálu ČÚZK za symbolickou cenu ve formátu PDF. Najdeme zde celkem 173 českých exonym pro polské území, z toho je jich 116 standardizovaných a zbývajících 57 je uvedeno kurzívou jako zastaralé, regionální či nestandardizované varianty. Dle slov autorů si publikace kromě zmapování současného úzu v užívání exonym klade za cíl české podoby zeměpisných jmen kodifikovat. Jejím cílem je zachycení a standardizování české exonymie v jejím současném rozsahu a stavu. „Index tak plní funkci normativní příručky pro všechny, kteří s českými exonymy přicházejí do styku - jak pro geografy, kartografy, historiky, lingvisty, novináře, rozhlasové a televizní redaktory a hlasatele, tak i pro širokou veřejnost“. (Český úřad zeměměřický a katastrální 2019: 10).

Problémem je však zejména fakt, že např. ve skupině pro překladatele $\mathrm{z}$ češtiny a polštiny, v níž byla v prosinci 2020 realizovaná malá anketa, nemá spousta překladatelů o existenci tohoto indexu vůbec ponětí. Většina z nich uvádí, že se při převodu zeměpisných jmen uchyluje nejčastěji na Wikipedii. V př́padě polského indexu exonym je však situace odlišná, spousta překladatelů z češtiny do polštiny jej zná a využívá. Dle našeho soudu zde může hrát roli samotný název české publikace, který obsahuje termín exonymum, jež je zřejmě pro překladatelskou komunitu méně známý.

7 Staženo na základě žádosti zde: ttps://geoportal.cuzk.cz/(S(koowpgakxnxbuvlr4xov4qc1))/Default.aspx?lng=CZ \& mode=TextMeta \& side=mapy_publikace \& metadataID=CZ-CUZK-EXONYMA-PDF \& head_tab=sekce-02-gp \& menu=24051 
Dalším zdrojem normativních informací jsou slovníky a normativní příručky češtiny. Přínosný je v tomto ohledu Česko-polský slovník (Siatkowski - Basaj 2002), jehož přílohou je seznam zeměpisných jmen. Najdeme zde pro oblast Polska 24 českých exonym. ${ }^{8}$ Další pomoc nabízí Pravidla českého pravopisu (Hlavsa et al. 2002), kde můžeme opět najít seznam zeměpisných jmen. Tato pomoc také není prílliš rozsáhlá, je zde uvedeno pouze 32 českých exonym pro polská toponyma. Na druhou stranu je u většiny zeměpisných jmen k dispozici tvar druhého pádu a odvozené přídavné jméno.

V již zmiňovaném Slovníku pohranič̌ jsou zaznamenána zejména vlastní jména z př́hraničního prostoru a jsou rozdělená do dvou oddílůa a to pro oba směry překladu z češtiny do polštiny i vice versa. Názvy některých méně známých zeměpisných objektů jsou zde zaznamenány na základě výzkumu reálného úzu obyvatel této oblasti. Autoři tohoto slovníku se kupříkladu v některých př́padech rozhodli doporučení KSNG nerespektovat a některé české objekty tak nachází svá polská pojmenování právě zde. V tomto případě se však nejedená o normativní slovník a autoři jsou vedeni snahou zmapovat skutečný úzus a jazykové bohatství této oblasti. Stejně tak zde najdeme mnohé české názvy polských geografických objektů. Bude tak jistě dalším cenným zdrojem informací.

Poslední instancí při hledání vhodných ekvivalentů by měla být již zmiňovaná Wikipedie, která je pro mnoho uživatelů v této oblasti základním nástrojem. Nesmíme také zapomenout na Google maps, kde je pro polské prostředí uvedena spousta inovativních a mnohdy až nepochopitelných novotvarů, které mnohdy vyvolávají úsměv na tváři (Ústí nad Svinou, Elbínek, Velkopolská Středa, Nový Štětín). K této proměně došlo v roce 2018. Do té doby se společnost Google držela strategie používat pro každou zemi její původní názvosloví. Ve světle panující tendence ke zjednodušování zeměpisného názvosloví a prosazování endonym se toto rozhodnutí zdá poněkud zvláštní a nekoncepční. Obzvlášt když přihlédneme k hlavnímu účelu použivání těchto map - tedy nalezení vhodné trasy či orientace $\mathrm{v}$ terénu.

\section{3 / POLSKÉ INDEXY EXONYM A SEZNAMY ZEMĚPISNÝCH NÁZVŮ}

Snahy o standardizaci zeměpisných názvů mají v Polsku poměrně dlouhou tradici. V roce 1951 byla ustanovena Komise pro standardizaci geografických názvů (KSNG), která započala rozsáhlé badatelské práce, které měly vést ke sjednocení geografických názvi̊ z celého světa použivaných v Polsku. Byla započata příprava pro vydání seznamu názvi̊, které jsou považovány za správné a doporučované (popolštěných i originálních).

Již v roce 1959 vydalo PWN ve Varšavě souhrnnou publikaci Polskie nazewnictwo geograficzne świata, ${ }^{10}$ která se stala neocenitelným pomocníkem v práci vydavatelů, editorů, geografů a kartografư. Jako normativní příručka se používala po několik desetiletí. V letech 1994-1996 pak vycházely pod hlavičkou KSNG ${ }^{11}$ postupně čtyři svazky seznamů, které se soustředily již pouze na popolštěné názvy čili exonyma (KSNG 1994). Celkově bylo v rámci tohoto počinu standardizová-

8 Pro opačný směr překladu je toto číslo daleko vyšší - viz níže.

9 Srov. (Chlebda - Dobrotová et al., 2015: 28)

10 Varšava, PWN, 1959.

11 Komisja Standaryzacji Nazw Geograficznych poza Granicami Rzeczypospolitej Polskiej 
no 6400 exonym z celého světa. Kromě 32 exonym pro česká města, 12 hydronym a 29 oronym zde najdeme samostatnou kapitolu věnovanou toponymům $\mathrm{z}$ Těšínského Slezska. V této sekci najdeme dalších 82 oikonym 13 hydronym a 17 oronym. Celkem tedy na tu dobu úctyhodných 182 exonym.

Již v roce 1994 tak KSNG standardizovala více exonym na území České republiky, než kolik jich bylo v rámci češtiny standardizováno pro území Polska dodnes. Do značné míry tento rozdíl vysvětluje právě fenomén Těšínského Slezska, které bylo dřive zhusta obýváno obyvateli polské národnosti. Proto se dodnes v polštině používá spousta tradičních a mnohdy původně polských toponym, která dala paradoxně základ českým endonymům.

Náš přehled však rokem 1994 zdaleka nekončí. V dalším období se autorskému týmu podařilo vydat 12 svazků Zeměpisného názvosloví světa (KSNG 2009), v nichž bylo zahrnuto celkem 53000 geografických objektů z celého světa a u $10000 \mathrm{z}$ nich se podařilo standardizovat polská exonyma. V 11. svazku vyšel seznam pro naši část Evropy a pro území ČR, v němž se uvádí 292 exonym + řada dalších pojmenování převzatých z češtiny v nezměněné podobě.

Jestliže byla $v$ těchto obdobích prosazována snaha o co nejrozsáhlejšś popolštování cizích toponym, došlo $\mathrm{v}$ poslední době $\mathrm{k}$ revizím a snaze vyškrtnout ze seznamu málo použivané či zastaralé výrazy. Poslední publikovaný seznam polských geografických názvů světa vyšel v roce 2013 v podobě jednoho svazku (KSNG 2013). Z výše zmíněných důvodů ze seznamu některá exonyma vypadla. Ve snaze o zdokumentování a zachování jazykového bohatství však proběhl další výzkum exonym na území, která dřive obývalo polské obyvatelstvo, což se promítlo v navýšení počtu exonym z Těšínského Slezska. Celkem zde tedy najdeme pro území České republiky 372 exonym.

\section{4 / ZÁVĚR}

Na základě našich rešerší se jeví, že uživatelé pátrající po polských zeměpisných názvech z českého prostředí mají při hledání správných ekvivalentů jednodušší situaci než jejich protějšky. V polském úředním seznamu se navíc doslovně uvádí, že pokud daný objekt v seznamu chybí, znamená to zároveň, že komise pro daný objekt polský název nedoporučuje, i kdyby byl uveden v některých dalších publikacích. Důvodem absence názvu v seznamu může být také fakt, že se jedná o nepř́liš významný objekt nebo že přestal existovat. ${ }^{12}$

$\mathrm{V}$ př́padě polských zeměpisných názvů tak nemusíme brát v potaz jiné zdroje - jako např. Seznam zeměpisných jmen v již zmiňovaném Česko-polském slovníku (Siatkowski - Basaj 2002), ve kterém je uvedeno 180 polských exonym. Navíc jsou všechny seznamy a publikace KSNG na rozdíl od českých seznamů volně dostupné na internetu, takže k nim má široká veřejnost snadný př́istup. V tomto ohledu je nadějným krokem počin Českého úřadu zeměměřičského a katastrálního, který nabízí stažení nejnovější verze indexu českých exonym z roku 2019 ve formátu pdf. Snad se tedy do budoucna dočkáme stejně přehledné situace i pro směr převodu z polštiny do češtiny.

Z výše uvedených úvah dále vyplývá předpoklad, že při převodu do polštiny by měli být uživatelé jednotnější, protože se mohou jednoznačně opřít o volně dostupný závazný seznam zeměpisných jmen, který pokrývá značně významnější procento z celkového počtu zeměpisných 
objektů. ${ }^{13}$ Uživatelé češtiny pak zřejmě budou při převodu více diverzifikovaní, nebot nemají podobně rozsáhlý seznam exonym pro Polsko k dispozici, a navíc není v českém kontextu stanoveno, že je Index českých exonym závazný. Zda tomu tak opravdu je, se pokusíme zjistit v rámci dalšího výzkumu.

Příspěvek vznikl za podpory MŠMT ČR udělené UP v Olomouci (IGA_FF_2020_013).

\section{ON THE ISSUE OF TOPONYMS CONVERSION BETWEEN CZECH AND POLISH - EXONYMS AND ENDONYMS}

SUMMARY The article focuses on the issue of translation of the geographical names of objects occurring in the Czech Republic and Poland in the language of the neighbour. Language users - especially translators and authors of texts on the subject of a neighbouring country - often face problems in this regard. The status of names codification for geographical objects located outside the area where the language has official status, differs in Poland and the Czech Republic in particular in terms of quantity. In addition to academic textbooks, bilingual dictionaries and dictionaries of geographical names, the text examines the available official lists of so-called exonyms as a reference point when looking for suitable solutions.

In Poland, the standardization of geographical names has been dealt with for years by the Commission for standardization of geographical names outside the Republic of Poland. In the last edition of the Official list of Polish geographical names of the world (Urzędowy wykaz polskich nazw geograficznych świata) from 2013 there were 327 Polish exonyms for Czech geographical objects. In cases not included in this list, the users should reach for Czech endonyms from the point of view of linguistic correctness.

However, only 173 Czech exonyms for Polish geographical objects were included in the last Czech exonym index from 2019, which, given the several times larger area of Poland, includes quite a small percentage of names. There is also a lack of a clear recommendation by the Czech land registry and geodetic authority on the mandatory use of this index, as well as guidance for the situation where we are dealing with a name that is missing in the index.

In accordance with global trends, there is a tendency in both languages to displace exonyms by endonyms. However, this trend is not always accurate and justified and authors should take into account many linguistic and extralinguistic factors.

13 Nesmíme také zapomínat, že Polsko má zhruba 4× větší rozlohu než Česká republika, což celý nepoměr ještě prohlubuje. 


\section{Z ZAGADNIEŃ PRZEKŁADU TOPONIMÓW MIĘDZY JĘZYKIEM CZESKIM I POLSKIM-ECZONIMY I ENDONIMY}

STRESZCZENIE Artykuł koncentruje się na problematyce przekładu nazw geograficznych obiektów występujących na terytorium Czech i Polski w języku sąsiada. Problemy w tym zakresie stawiają nieraz wyzwania przed użytkownikami języka - zwłaszcza tłumaczami oraz autorami tekstów na temat sąsiedniego kraju. Stan kodyfikacji nazw dla obiektów geograficznych znajdujących się poza obszarem, gdzie ten język ma status oficjalny, w Polsce i Czechach różni się zwłaszcza pod względem ilościowym. Oprócz podręczników akademickich, słowników dwujęzycznych oraz słowników nazw geograficznych bada tekst dostępne oficjalne wykazy tzw. egzonimów stanowiące punkt odniesienia podczas szukania odpowiednich rozwiązań.

W Polsce standardyzacją nazw geograficznych od lat zajmuje się Komisja Standaryzacji Nazw Geograficznych poza Granicami Rzeczypospolitej Polskiej. W ostatniej edycji Urzędowego wykazu polskich nazw geograficznych świata z roku 2013 odnotowano 327 polskich egzonimów dla czeskich obiektów geograficznych. W wypadkach nie uwzględnionych w tym wykazie użytkownicy powinni z punktu widzenia poprawności językowej używać czeskich endonimów.

W ostatnim czeskim indeksie egzonimów z 2019 r. uwzględniono natomiast tylko 173 czeskich egzonimów dla polskich obiektów geograficznych, co biorąc pod uwagę kilka razy większą powierzchnię Polski nie obejmuje zbyt dużego procentu nazw. Brakuje również jednoznacznej rekomendacji Czeskiego Instytutu Geodezyjnego i Katastralnego w sprawie obowiązkowego korzystania $\mathrm{z}$ tego indeksu jak również wskazówek w sytuacjach, kiedy mamy do czynienia z nazwą, której w indeksie brakuje.

Zgodnie z globalnymi trendami obserwujemy w obu językach tendencję do wypierania egzonimów przez endonimy. Nie zawsze ta tendencja jest jednak trafna i uzasadniona i autorzy powinni brać pod uwagę wiele czynników językowych oraz pozajęzykowych.

\section{LITERATURA}

I Beránek T. et al., 2006, Index českých exonym-standardizované podoby, varianty (edice Geografické názvoslovné seznamy OSN - ČR), Praha.

I Čáslavka I. - Štusáková H. -Vyskočilová P., 1981, Vžitá česká vlastní jména geografická, Praha.

I Český úřad zeměměřický a katastrální, 2019, Index českých exonym PDF. Standardizované podoby, varianty, Praha.

I Grzenia J., 2002, Stownik nazw własnych, Warszawa.

I Grzenia J., 2008, Stownik nazw geograficznych z odmiana i wyrazami pochodnymi, Warszawa.

I Harvalík M., 1998, K problému klasifikace exonym, „Slovo a slovesnost“, 59, s. 259-261.

I Harvalík M., 1998, Vývojové etapy a současný stav české exonymie, „Naše řeč“, 81, s. 240-244.

I Harvalík M., 2004, Exonyma a cizí zeměpisná jména v češtině, Synchronní a diachronní aspekty čské onymie, Praha. 
I Hlavsa Z. et al. (eds.), 2002, Pravidla českého pravopisu -s Dodatkem Ministerstva školství, mládeže a tělovýchovy České republiky, Praha.

I Chlebda W. - Dobrotová I. ed al. (eds.), 2015, Tématický česko-polsko-ruský polsko-česko-ruský slovník pohraničí, Opole.

I KSNG, 1994, Polskie nazwy geograficzne świata. Część 1.: Europa (bez Europy Wschodniej), (I. Krauze-Tomczyk \& J. Kondracki, eds.), Warszawa.

I KSNG, 2009, Nazewnictwo geograficzne świata. Zeszyt11. Europa, Część I, Warszawa.

I KSNG, 2013, Urzędowy wykaz polskich nazw geograficznych świata, (M. Zych, ed.), Warszawa.

I Lotko E., 1986, Čeština a polština v prekladatelské a tlumočnické praxi, Ostrava.

I Lotko E., 1997, Synchronní konfrontace čěstiny a polštiny: soubor statí, Olomouc.

I Nový encyklopedický slovník češtiny (2012-2020), Brno, https://www.czechency.org. [cit.: 2.9.2020]

I Pleskalová J., 2014, Vlastníjména v češtině, Brno.

I Rzetelska-Feleszko E., 1998, Polskie nazwy własne: encyklopedia, Warszawa: Wydaw. IJP PAN, Warszawskie Towarzystwo Naukowe, Polska Akademia Nauk, Instytut Języka Polskiego (eds.).

I Siatkowski J. - Basaj M., 2002, Słownik czesko-polski, wydanie 2 zaktualizowane, Warszawa.

I Šrámek R., 1997, Cizí místní jména v češtině, Český jazyk na prèlomu tisíciletí, red. Fr. Daneš a kol., Praha, s. 280-286.

I Šrámek R., 1999, Úvod do obecné onomastiky, Brno. 